\title{
Chemical composition and biological activities of the essential oils from Vitex-agnus castus, Ocimum campechianum and Ocimum carnosum
}

\author{
LARA P. RICARTE, GABRIELI P. BEZERRA, NIRLA R. ROMERO, HORLANDO C. DA \\ SILVA, TELMA L.G. LEMOS, ANGELA M.C. ARRIAGA, PÉRICLES B. ALVES, \\ MARCELO B. DOS SANTOS, GARDENIA C.G. MILITÃO, THIAGO D.S. SILVA, \\ RAIMUNDO BRAZ-FILHO \& GILVANDETE M.P. SANTIAGO
}

\begin{abstract}
The essential oils obtained by hydrodistillation from fresh leaves of Vitex agnus-castus and Ocimum campechianum, and from fresh inflorescences of Ocimum carnosum were analysed by GC-FID and GC-MS. The major components of $V$. agnus-castus essential oil were identified as 1,8-cineole (47.9\%), terpinyl $\alpha$-acetate (11.6\%), sabinene (11.2\%) and caryophyllene oxide (9.7\%), while in the 0 . campechianum essential oil were eugenol (72.1\%), $\beta$-elemene (6.8\%), (E)-caryophyllene (6.4\%) and bicyclogermacrene (5.2\%). Linalool (79.0\%), $\alpha$-epi-cadinol (5.4\%), terpinen-4-ol (3.2\%) and 1,8-cineole (2.8\%) were the major constituents in the 0 . carnosum essential oil. The essential oils were subsequently evaluated for their larvicidal and cytotoxic activities. Larval bioassay against Aedes aegypti of $V$. agnus-castus, $O$. campechianum and $O$. carnosum essential oils showed $\mathrm{LC}_{50}$ values of $97.55 \pm 0.35,81.45 \pm 0.35$ and $109.49 \pm 0.35 \mu \mathrm{g} / \mathrm{mL}$, respectively. The in vitro cytotoxic activities of the essential oils has been evaluated on breast adenocarcinoma (MCF-7), lung carcinoma (NCl-H292), pro-myelocytic leukemia (HL-60), and cervical adenocarcinoma (HEP-2) human cell lines, and pro-myelocytic leukemia cells lines ( $\mathrm{HL}-60)$ were found to be the most sensitive to all the essential oils tested than the others. This is the first report on larvicidal and cytotoxic activities of these essential oils.
\end{abstract}

Key words: Aedes aegypti, Cytotoxic activity, Lamiaceae, Larvicidal activity.

\section{INTRODUCTION}

Aedes aegypti Linnaeus (Diptera: Culicidae) is the main vector of dengue, chikungunya, and Zika virus. This species is widely distributed in the tropical and subtropical countries, where environmental and climatic conditions of temperature and humidity allow its proliferation (Jansen \& Beebe 2010, Fujiwara et al. 2017). In addition, the geographical range of Ae. aegypti is increasing due to rapid urbanization and increased global movement of people and cargo
(AlShebly et al. 2017). There are no specific drugs for the treatment of these diseases; therefore, the best strategy available to reduce the incidence of these viral diseases is the control of the insect vector (Moreira et al. 2016). Synthetic insecticides and insect growth regulators are widely used to reduce larval instars of mosquitoes. However, the frequent use of these insecticides can result in insecticide resistance, environmental pollution, and risks to human and other organisms (AlShebly et al. 2017). 
Cancer is a disease that contributes to the uncontrolled growth and invasion of the abnormal cells leading to the formation of tumor, and is one the major causes of death worldwide. Chemotherapy is an important cancer treatment. However, the high cost, increasing multidrug resistance, and side effects direct the search for alternative chemotherapeutic agents (Gautam et al. 2014, Campos-Xolalpa et al. 2017).

Plants essential oils can be used as alternative sources of Ae. aegypti larval control agents (Aguiar et al. 2010, Gois et al. 2011, Dias \& Moraes 2014, Pavela 2015, Carvalho et al. 2016, De Sousa et al. 2016, Mendes et al. 2017, Nascimento et al. 2017, Mar et al. 2018), and have been reported to show cytotoxic activity when tested on human cancer cell lines (Gautam et al. 2014, Lesgards et al. 2014, De Sousa et al. 2016, Kumar et al. 2016, Saleh et al. 2017, Tavakoli et al. 2017, vasilijevic et al. 2018).

In this context, this study reports the larvicidal and cytotoxic activities of the essential oils from leaves of Vitex agnus-castus L. (Lamiaceae) and Ocimum campechianum Mill. (Lamiaceae), formely O. micranthum, and from inflorescences of Ocimum carnosum (Spreng) Link \& Otto ex Benth (Lamiaceae), formely 0. selloi, as well as their chemical composition.

\section{MATERIALS AND METHODS}

\section{Plant material}

The leaves of of Vitex agnus-castus and Ocimum campechianum, and the inflorescences of Ocimum carnosum were collected in August 2016 from the Horto de Plantas Medicinais Professsor Francisco José de Abreu Matos (Fortaleza, Ceará, Brazil). Plant materials were authenticated by Luiz Wilson Lima-Verde, and voucher specimens (\#60102, \#60105 and \#60104) were deposited at the Herbário Prisco Bezerra (EAC), Departamento de Biologia, Universidade Federal do Ceará, Brazil.

\section{Extraction of the essential oils}

Fresh leaves of $V$. agnus-castus and $O$. campechianum, and fresh inflorescences of 0 . carnosum were subjected to hydrodistillation in a Cleavenger-type apparatus for 2 hours. The isolated oils, after drying over anhydrous sodium sulfate and filtration, were stored in sealed glass vials and maintained under refrigeration until further analysis. The yields $(\mathrm{w} / \mathrm{w})$ were calculated based on the fresh weight of the botanical material.

\section{GC/MS and GC analysis of essential oils}

GC analyses were performed using a GC-MS/ FID (QP2010 Ultra, Shimadzu Corporation, Kyoto, Japan) equipped with an autosampler AOC-20i (Shimadzu). Separations were accomplished using a Rtx ${ }^{\circledR}-5 \mathrm{MS}$ Restek fused silica capillary column (5\%-diphenyl-95\%-dimethyl polysiloxane) of $30 \mathrm{~m} \times 0.25 \mathrm{~mm}$ i.d., $0.25 \mathrm{~mm}$ film thickness, at a constant helium (99.999\%) flow rate of $1.2 \mathrm{~mL} / \mathrm{min}$. The essential oils were dissolved in ethyl acetate $(5 \mathrm{mg} / \mathrm{mL})$ and an injection volume of $0.5 \mu \mathrm{L}$ was employed, with a split ratio of 1:10. The oven temperature was programmed from $50^{\circ} \mathrm{C}$ (isothermal for 1.5 min), with an increase of $4^{\circ} \mathrm{C} / \mathrm{min}$, to $200^{\circ} \mathrm{C}$, then $10^{\circ} \mathrm{C} / \mathrm{min}$ to $250^{\circ} \mathrm{C}$, ending with a $5 \mathrm{~min}$ isothermal at $250^{\circ} \mathrm{C}$.

The MS and FID data were simultaneously acquired employing a Detector Splitting System; the split flow ratio was 4:1 (MS:FID). A $0.62 \mathrm{mx}$ $0.15 \mathrm{~mm}$ i.d. restrictor tube (capillary column) was used to connect the splitter to the MS detector; a $0.74 \mathrm{~m} \times 0.22 \mathrm{~mm}$ i.d. restrictor tube was used to connect the splitter to the FID detector. The MS data (total ion chromatogram, TIC) were acquired in the full scan mode $(\mathrm{m} / \mathrm{z}$ 
40-350) at a scan rate of 0.3 scan/s using the electron ionization (EI) with an electron energy of $70 \mathrm{eV}$. The injector temperature was $250^{\circ} \mathrm{C}$ and the ion-source temperature was $250^{\circ} \mathrm{C}$. The FID temperature was set to $250^{\circ} \mathrm{C}$, and the gas supplies for the FID were hydrogen, air, and helium at flow rates of 30,300 , and $30 \mathrm{~mL} / \mathrm{min}$, respectively. Quantification of each constituent was estimated by FID peak-area normalization (\%). Compound concentrations were calculated from the GC peak areas and they were arranged in order of GC elution.

\section{Identification of essential oils constituents}

The identification of individual components of the essential oils was performed by computerized matching of the acquired mass spectra with those stored in NIST21, NIST107 and WILEY8 mass spectral library of the GC-MS data system. A mixture of hydrocarbons $\left(\mathrm{C}_{9} \mathrm{H}_{20}-\mathrm{C}_{19} \mathrm{H}_{40}\right)$ was injected under these same conditions and identification of constituents was then performed by comparing the spectra obtained with those of the equipment data bank and by the Kovats index, calculated for each constituent as previously described (Adams 2007). Retention indices were obtained with equation proposed by van Den Dool \& Kratz (1963).

\section{Larvicidal biossay}

Aliquots of the essential oils tested (12.5 to $500 \mu \mathrm{g} / \mathrm{mL}$ ) were placed in a beaker $(50 \mathrm{~mL})$ and dissolved in DMSO/ $\mathrm{H}_{2} \mathrm{O}$ 1.5\% (20 mL). Fifty instar III larvae of Ae. aegypti were delivered to each beaker. For each experiment, both positive (Temephos $\left.{ }^{\circ}\right)$ and negative $\left(\mathrm{H}_{2} \mathrm{O} /\right.$ DMSO 1.5\%) control assays were carried out in parallel. After 24 hours, at room temperature, the number of dead larvae was counted and the lethal percentage calculated. For each sample, 3 independent experiments were run
(Oliveira et al. 2002). Larvae of Ae. aegypti were collected from mosquito colonies maintained at NUVET - SESA (Núcleo de Controle de Endemias Transmissiveis por Vetor - Secretaria de Saúde do Estado do Ceará).

\section{Cytotoxicity assay}

The human tumor cell lines used were breast adenocarcinoma (MCF-7), lung carcinoma (NCl-H292), pro-myelocytic leukemia (HL-60), and cervical adenocarcinoma (HEP-2) which were obtained from the Banco de Células do Rio de Janeiro (RJ, Brazil). Cancer cells were maintained in RPMI 1640 medium or DMEN supplemented with $10 \%$ fetal bovine serum, $2 \mathrm{~mm} / \mathrm{L}$ glutamine, $100 \mathrm{U} / \mathrm{mL}$ penicillin, $100 \mu \mathrm{g} / \mathrm{mL}$ streptomycin at $37{ }^{\circ} \mathrm{C}$ with $5 \% \mathrm{CO}_{2}$. The cytotoxic activities of essential oils were tested against four human tumor cell lines using the 3-(4,5-dimethylthiazol2-yl)-2,5-diphenyl-2H-tetrazolium bromide (MTT; Sigma Aldrich Co., St. Louis, MO, USA) reduction assay (Mosmann 1983). For all experiments, tumor cells were plated in 96 -well plates $\left(10^{5}\right.$ cells $/ \mathrm{mL}$ for adherent cells or $3 \times 10^{5}$ cells $/ \mathrm{mL}$ for leukemia). The essential oils dissolved in DMSO $1 \%$ were added to each well and incubated for 72 h. Control groups received the same amount of DMSO. The compound concentrations added to the cells ranged from 0.39 to $25.00 \mu \mathrm{g} / \mathrm{mL}$. After $69 \mathrm{~h}$ of treatment, MTT $(0.5 \mathrm{mg} / \mathrm{mL})$ was added, three hours later, the MTT formazan product was dissolved in $100 \mu \mathrm{L}$ of DMSO, and absorbance was measured at $570 \mathrm{~nm}$ in plate spectrophotometer (Varioskan Flask, Thermo Scientific). Doxorubicin was used as positive control. $I C_{50}$ values and their $95 \%$ confidence intervals for two different experiments were obtained by non linear regression using Graphpad Prism version 5.0 for Windows (GraphPad Software, San Diego, California, USA). 


\section{RESULTS}

\section{Chemical analysis of the essential oils}

The yields of essential oils obtained by the hydrodistillation of fresh leaves of $V$. agnuscastus and $O$. campechianum, and of fresh inflorescences of $O$. carnosum were $0.1 \%, 0.4 \%$ and $0.5 \%(\mathrm{w} / \mathrm{w})$, respectively, in relation to the weight of the plant material. The chemical composition of the essential oils, including the retention index and the percentage relative of each constituent identified, is shown in Table I. The GC chromatograms of essential oils from the leaves of $V$. agnus-castus and $O$. campechianum, and from inflorescences of 0 . carnosum are presented in Figures 1, 2 and 3, respectively.

In the essential oil from leaves of $V$. agnuscastus, nine constituents were identified representing $100.0 \%$ of the total composition. The components of this essential oil were identified as 1,8 -cineole (47.9\%), terpinyl $\alpha$-acetate (11.6\%), sabinene $(11.2 \%)$, caryophyllene oxide (9.7\%), terpinen-4-ol (4.6\%), (E)-caryophyllene (4.4\%), spathulenol (4.4\%), a-epi-cadinol (4.2\%) and bicyclogermacrene (2.0\%). The monoterpene and sesquiterpene fractions represent $75.3 \%$ and $24.7 \%$ of the oil, respectively.

Table I. Chemical composition of essential oils of V. agnus-castus, 0 . campechianum and 0 . carnosum.

\begin{tabular}{|c|c|c|c|c|c|c|}
\hline $\begin{array}{l}\text { Compound } \\
\text { Sabinene }\end{array}$ & $\begin{array}{c}\text { RT }\left(^{(\min )^{\mathrm{a}}}\right. \\
11.62\end{array}$ & $\begin{array}{l}\text { RRI exp. } \\
960\end{array}$ & $\begin{array}{l}\text { RRI lit. }{ }^{\text {c }} \\
969\end{array}$ & $\begin{array}{c}\text { V. agnus-castus } \\
\text { (\%) } \\
11.2\end{array}$ & $\begin{array}{c}0 . \\
\text { campechianum } \\
(\%) \\
-\end{array}$ & $\begin{array}{c}0 . \\
\text { carnosum } \\
(\%) \\
-\end{array}$ \\
\hline 1,8-Cineole & 13.83 & 1025 & 1026 & 47.9 & 2.9 & 2.8 \\
\hline Fenchone & 16.07 & 1081 & 1083 & - & - & 2.2 \\
\hline Linalool & 16.42 & 1089 & 1095 & - & - & 79.0 \\
\hline Camphor & 18.30 & 1137 & 1146 & - & - & 2.2 \\
\hline Terpinen-4-ol & 19.57 & 1170 & 1174 & 4.6 & - & 3.2 \\
\hline$\delta$-Elemene & 25.47 & 1335 & 1335 & - & 1.2 & - \\
\hline Terpinyl $\alpha$-acetate & 25.83 & 1344 & 1346 & 11.6 & - & - \\
\hline Eugenol & 26.20 & 1355 & 1356 & - & 72.1 & - \\
\hline$\beta$-Elemene & 27.41 & 1388 & 1389 & - & 6.8 & - \\
\hline (E)-Caryophyllene & 28.48 & 1416 & 1417 & 4.4 & 6.4 & - \\
\hline$\alpha$-Trans-Bergamotene & 28.88 & 1429 & 1432 & - & - & 2.8 \\
\hline$\alpha$-Humulene & 29.65 & 1452 & 1452 & - & 1.3 & - \\
\hline Germacrene D & 30.56 & 1481 & 1484 & - & - & 2.4 \\
\hline Bicyclogermacrene & 31.07 & 1496 & 1500 & 2.0 & 5.2 & - \\
\hline Elimicine & 32.75 & 1547 & 1555 & - & 4.1 & - \\
\hline Spathulenol & 33.72 & 1576 & 1577 & 4.4 & - & - \\
\hline Caryophyllene oxide & 33.92 & 1582 & 1582 & 9.7 & - & - \\
\hline$\alpha$-Epi-Cadinol & 35.61 & 1647 & 1638 & 4.2 & - & 5.4 \\
\hline Monoterpenes & & & & 75.3 & 2.9 & 89.4 \\
\hline Sesquiterpenes & & & & 24.7 & 20.9 & 10.6 \\
\hline Phenylpropanoids & & & & - & 76.2 & - \\
\hline Total identified & & & & 100.0 & 100.0 & 100.0 \\
\hline
\end{tabular}

${ }^{\mathrm{a}}$ Retention time; ${ }^{\mathrm{b}}$ Relative retention index calculated against $n$-alkanes $\left(\mathrm{C}_{9} \mathrm{H}_{20}-\mathrm{C}_{19} \mathrm{H}_{40}\right)$ applying the Van den Dool \& Kratz (1963) equation; 'Relative retention index from the literature (Adams, 2007). 
Eight compounds, representing 100\% of the essential oil from leaves of 0 . campechianum have been identified. Eugenol (72.1\%), $\beta$-elemene (6.8\%), (E)-caryophyllene (6.4\%), bicyclogermacrene (5.2\%), elimicine (4.1\%), 1,8-cineole (2.9\%), $\alpha$-humulene (1.3\%) and $\delta$-elemene (1.2\%) were the components. Phenylpropanoids (76.2\%), sesquiterpenes (20.9\%) and monoterpenes (2.9\%) were found in this oil.
In the essential oil obtained from inflorescences of $O$. carnosum, eight constituents were identified. The components were linalool (79.0\%), a-epi-cadinol (5.4\%), terpinen-4-ol (3.2\%), 1,8-cineole (2.8\%), germacrene D (2.4\%), $\alpha$-trans-bergamotene (2.8\%), fenchone (2.2\%) and camphor (2.2\%). This essential oil consists of $10.6 \%$ of sesquiterpenes and $89.4 \%$ of monoterpenes.

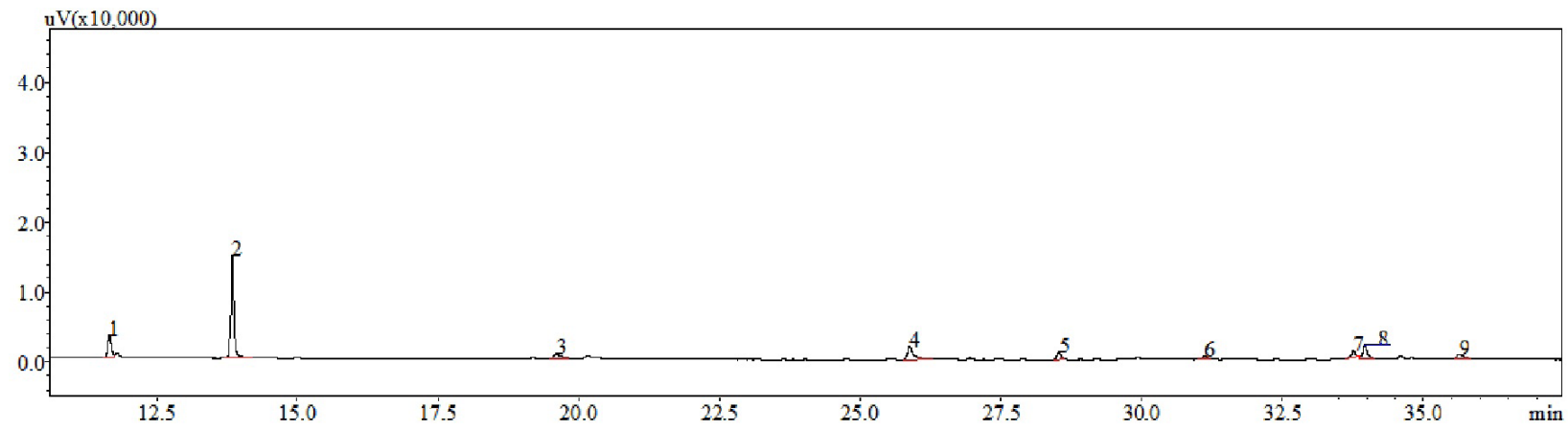

Figure 1. Chromatogram (CG-DIC) of essential oil from leaves of Vitex agnus-castus.

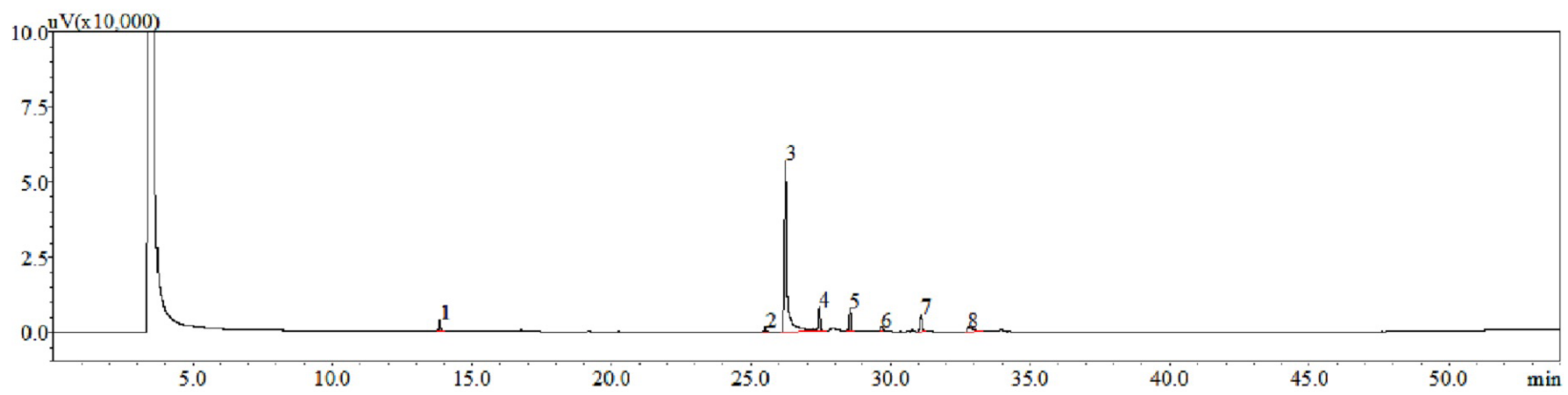

Figure 2. Chromatogram (CG-DIC) of essential oil from leaves of Ocimum campechianum.

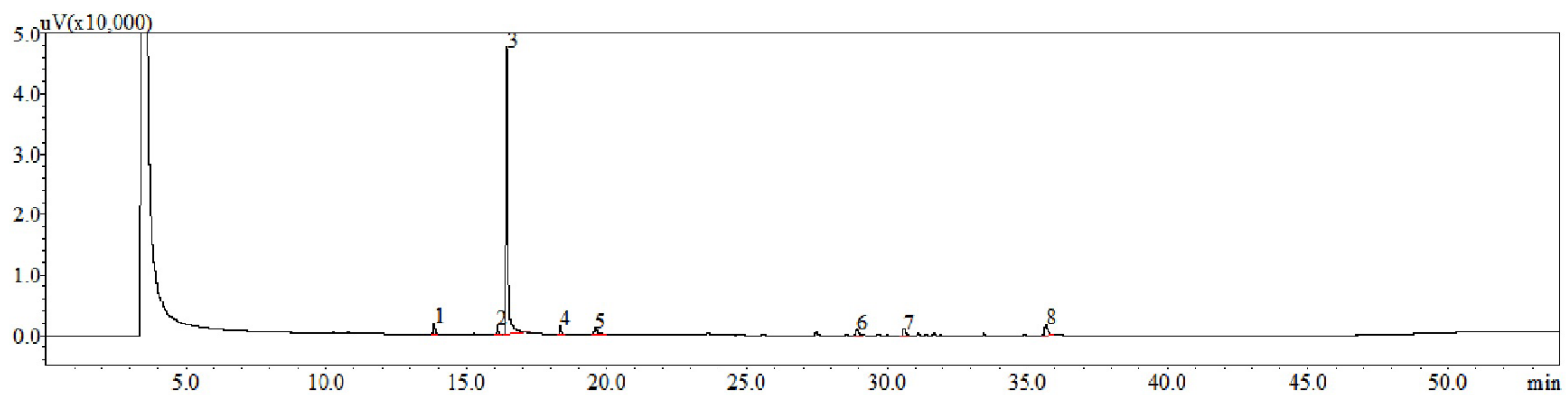

Figure 3. Chromatogram (CG-DIC) of essential oil from inflorescences of Ocimum carnosum. 


\section{Larvicidal activity}

Essential oils from leaves of $V$. agnus-castus and 0 . campechianum, and from inflorescences of $O$. carnosum were screened for their activity against instar III larvae of Ae. aegypti. The mortality percentages were calculated after 24 h. The larvicidal effects of tested essential oils against instar III Ae. aegypti larvae are shown in Table II. In our experiments, the mortality of larvae ranged from $100 \%$ to $0 \%$, when Ae. aegypti larvae were treated with the tested essential oils (Table II). 0,0'-(Thiodi-4,1-phenylene)bis(0,0dimethyl phosphorothioate (Temephos ${ }^{\circledR}$ ) was used as a positive control ( $\left.\mathrm{LC}_{50} 1.4 \pm 0.2 \mu \mathrm{g} / \mathrm{mL}\right)$.

Additional data on the toxicity of essential oils have been obtained by calculation of their $\mathrm{LC}_{50}$ values and, thus the essential oils obtained from leaves of $V$. agnus-castus and o. campechianum and from inflorescences of
O. carnosum showed $\mathrm{LC}_{50}$ values of $97.55 \pm 0.35$, $81.45 \pm 0.35$ and $109.49 \pm 0.35 \mu \mathrm{g} / \mathrm{mL}$, respectively.

\section{Cytotoxic activity}

The essential oils from $V$. agnus-castus, 0. campechianum and $O$. carnosum were submitted to the 3-(4,5-dimethylthiazol-2-yl)-2,5-diphenyl$2 \mathrm{H}$-tetrazolium bromide (MTT) assay (Mosmann 1983) for the evaluation of their cytotoxic effects on breast adenocarcinoma (MCF-7), lung carcinoma ( $\mathrm{NCl}-\mathrm{H} 292)$, pro-myelocytic leukemia (HL-60), and cervical adenocarcinoma (HEP-2) human cell lines (Table III). Doxorubicin was used as the positive control. The essential oils from V. agnus-castus, O. campechianum, O. carnosum were more active against promyelocytic leukemia $(\mathrm{HL}-60)$ cell lines with $\mathrm{IC}_{50}$ values of $3.8,7.6$, and $13.2 \mu \mathrm{g} / \mathrm{mL}$, respectively (Table III).

Table II. Larval mortality (\%) of essential oils against third-instar of Aedes aegypti larvae.

\begin{tabular}{|c|c|c|c|}
\hline \multirow{2}{*}{ Concn $(\mu \mathrm{g} / \mathrm{mL})$} & \multicolumn{3}{|c|}{ Average (\%) of dead larvae after $\mathbf{2 4} \mathbf{h}^{\mathbf{a}}$} \\
\cline { 2 - 4 } & Vitex agnus-castus & Ocimum campechianum & Ocimum carnosum \\
\hline $\mathbf{5 0 0}$ & 100 & 100 & 100 \\
\hline $\mathbf{2 5 0}$ & 100 & 100 & 100 \\
\hline $\mathbf{1 0 0}$ & 52.67 & 69.33 & 23.33 \\
\hline $\mathbf{5 0}$ & 5.33 & 12.57 & 0.67 \\
\hline $\mathbf{2 5}$ & 0 & 0 & 0 \\
\hline $\mathbf{1 2 . 5}$ & 0 & 0 & 0 \\
\hline
\end{tabular}

${ }^{a}$ The results were means of three independent experiments.

Table III. Cytotoxic activity of essential oils.

\begin{tabular}{|c|c|c|c|c|}
\hline \multirow{2}{*}{$\begin{array}{c}\text { Essential oil and positive } \\
\text { control }\end{array}$} & \multicolumn{3}{|c|}{ IC $_{\mathbf{5 0}}(\boldsymbol{\mu g} / \mathbf{m L})(\mathbf{9 5 \%}$ confidence intervals) } \\
\cline { 2 - 5 } & MCF-7 & NCl-H292 & HL-60 & HEP-2 \\
\hline Vitex agnus-castus & $32.4(26.4-39.7)$ & $46.5(40.1-53.8)$ & $3.8(1.7-8.2)$ & $41.7(29.9-58.2)$ \\
\hline Ocimum campechianum & $20.3(12.1-31.9)$ & $37.2(33.4-41.5)$ & $7.6(4.3-13.6)$ & $31.4(23.8-41.5)$ \\
\hline Ocimum carnosum & $25.5(17.8-36.4)$ & $>50$ & $13.2(8.1-21.7)$ & $20.1(14.2-23.8)$ \\
\hline Doxorubicin & $0.30(0.19-0.53)$ & $0.30(0.10-0.40)$ & $0.03(0.01-0.03)$ & $0.70(0.30-1.70)$ \\
\hline
\end{tabular}

\footnotetext{
${ }^{\mathrm{a}}$ The results were means of two independent experiments.
} 


\section{DISCUSSION}

Essential oils are obtained from aromatic plants, mainly by steam distillation or hydrodistillation. They are considered promising in the control of mosquitoes as Ae. aegypti because consist of a mixture of volatile substances with a variety of functional groups that can be toxic to insects (Bakkali et al. 2008, Dias \& Moraes 2014). In the larvicidal activity of essential oils, the lipophilicity of their chemical constituents is associated with the percutaneous permeation of essential oils (El-Kattan et al. 2001).

The large abundance of monoterpenoid compounds, mainly 1,8-cineole, in the leaf essential oil of $V$. agnus-castus is in accordance with previous findings (Borges et al. 2012, Dervishi-Shengjergji et al. 2014, Neves \& Da Camara 2016). It is important to note that only 9 constituents were identified in this essential oil, and this number is similar to that reported for other sample collected in the northeastern Brazil, which presented 11 constituents (Borges et al. 2012). Monoterpenes have been reported to display larvicidal and insecticidal activities (Santos et al. 2011, Michaelakis et al. 2014, Liu et al. 2015, Polatoglu et al. 2017). The constituents 1,8-cineole (Araújo et al. 2003, Lucia et al. 2007, Cheng et al. 2009), terpinyl $\alpha$-acetate (Cheng et al. 2009, Pandey et al. 2013), and sabinene (Govindarajan 2010, Cheng et al. 2013) have shown larvicidal or insecticidal activity against Ae. aegypti, and these constituents were detected in the essential oil from leaves of $V$. agnus-castus.

The presence of the phenylpropanoid eugenol in the essential oil from leaves of 0 . campechianum, as a major chemical constituent, is in accordance with previous reports (Sacchetti et al. 2004, Silva et al. 2004, Trevisan et al. 2006, Vieira et al. 2014). Earlier investigations into the essential oils of this species growing in the same place, under same conditions, have found similar chemical composition (Silva et al. 2004, Trevisan et al. 2006, Vieira et al. 2014). It is generally admitted that the major constituents determine the biological properties of the essential oils (Riella et al. 2012, Dias \& Moraes 2014). In this way, the larvicidal effect of this essential oil can be attributed to eugenol, which has been reported to exhibit activity against $A$. aegypti larvae (Walıwitıya et al. 2009, Barbosa et al. 2012, Medeiros et al. 2013, Dias \& Moraes 2014, Fayemiwo et al. 2014).

In the present study, the major constituent identified in the essential oil from inflorescences of 0 . carnosum was linalool (79.0\%), whereas the literature reports methyl chavicol (92.5\%) and methyl eugenol (66.2\%) from two different accessions (Martins et al. 1997), trans-anethole (41.3\%) and methyl chavicol (27.1\%) (Moraes et al. 2002), as the major constituents. The variations in the chemical composition may be related with chemotypes for the same species or as a result of factors such as temperature, soil type, climate, and developmental and physiological differences (Nascimento et al. 2011, Fayemiwo et al. 2014). The essential oil of O. carnosum, which has linalool as the major constituent, exhibited larvicidal activity, with $\mathrm{LC}_{50}$ value of $109.49 \pm$ $0.35 \mu \mathrm{g} / \mathrm{mL}$. In previous studies, Jantan et al. (2005), Pandey et al. (2013) and Fujiwara et al. (2017) evaluated the larvicidal activity of linalool against $A$ e. aegypti, and observed $\mathrm{LC}_{50}$ values of $157.4,242.6$ and $275.2 \mu \mathrm{g} / \mathrm{mL}$, respectively. Therefore, it is possible that other constituents of the essential oil work synergistically with linalool.

Among the essential oils evaluated against Ae. aegypti larvae, the leaf essential oil of $O$. campechianum was the most active with $\mathrm{LC}_{50}$ value of $81.45 \pm 0.35 \mu \mathrm{g} / \mathrm{mL}$, and generally, all phenylpropanoid-rich essential oils exhibited larvicidal activity (Dıas \& Moraes 2014). 
The cytotoxic activity of 1,8-cineole (Moteki et al. 2002, Sampath et al. 2017), eugenol (Rajput et al. 2017, Fangjun \& Zhijia 2018), and linalool (Cheng et al. 2017, Aprotosoaie et al. 2014), major constituents in V. Agnus-castus, $O$. campechianum and $O$. carnosum essential oils, respectively, has been shown in previous studies. Therefore, it is possible that these constituents of the essential oils work synergistically to produce the cytotoxic activity of tested essential oils.

\section{CONCLUSIONS}

The results obtained show that the essential oils, especially that obtained from leaves of 0 . campechiamum could be considered as natural larvicidal agents. With respect to cytotoxic activity, pro-myelocytic leukemia cells lines ( $\mathrm{HL}$ 60) were found to be the most sensitive to all the essential oils tested than the others. These findings indicate that that the differences in the activities of the essential oils were related to their chemical composition.

\section{Acknowledgments}

The authors thank the Brazilian agencies Conselho Nacional de Desenvolvimento Científico e Tecnológico (CNPq), Coordenação de Aperfeiçoamento de Pessoal de Nivel Superior (CAPES), FUNCAP, PRONEX for fellowships and financial support, and Laboratório de Entomologia, Núcleo de Controle de Vetores do Ceará, Secretaria de Saúde do Estado do Ceará, Brazil, where the larvicidal bioassays were performed.

\section{REFERENCES}

ADAMS RP. 2007. Identification of essential oil components by gas chromatography/mass spectroscopy. Carol Stream, Illinois: Allured Publishing Corporation, 804 p.
AGUIAR JCD ET AL. 2010. Chemical constituents and larvicidal activity of Hymenaea courbaril fruit peel. Nat Prod Commun 5: 1977-1980.

ALSHEBLY MM, ALQAHTANI FS, GOVINDARAJAN M, GOPINATH K, VIJAYAN P \& BENELLI G. 2017. Toxicity of ar-curcumene and epi- $\beta$-bisabolol from Hedychium larsenii (Zingiberaceae) essential oil on malaria, chikungunya and St. Louis encephalitis mosquito vectors. Ecotoxicol Environ Safe 137: 149-157.

APROTOSOAIE AC, HANCIANU M, COSTACHE II \& MIRON A. 2014. Linalool: a review on a key odorant molecule with valuable biological properties. Flavour Frag J 29: 193-219.

ARAÚJO ECC, SILVEIRA ER, LIMA MAS, ANDRADE NETO M, DE ANDRADE IL, LIMA MAA, SANTIAGO GMP \& MESQUITA ALM. 2003. Insecticidal activity and chemical composition of volatile oils from Hyptis martiusii Benth. J Agric Food Chem 51: 3760-3762.

BAKKALI F, AVERBECK S, AVERBECK D \& IDAOMAR M. 2008. Biological effects of essencial oils - a review. Food Chem Toxicol 46: 446-475.

BARBOSA JDF, SILVA VB, ALVES PB, GUMINA G, SANTOS RLC, SOUSA DP \& CAVALCANTI SCH. 2012. Structure-activity relationships of eugenol derivatives against Aedes aegypti (Diptera: Culicidae) larvae. Pest Manag Sci 68: 1478-1483.

BORGES AR, AIRES JRA, HIGINO TMM, DE MEDEIROS MGF, CITÓ AMGL, LOPES JAD \& DE FIGUEIREDO RCBQ. 2012. Trypanocidal and cytotoxic activities of essential oils from medicinal plants of Northeast of Brazil. Exp Parasitol 132: 123-128.

CAMPOS-XOLALPA N, ALONSO-CASTRO AJ, SÁNCHEZ-MENDOZA E, ZAVALA-SÁNCHEZ MA \& PÉREZ-GUTIÉRREZ S. 2017. CytotoxiC activity of chloroform extract and four diterpenes isolated from Salvia ballotiflora. Braz J Pharmacog 27: 302-305.

CARVALHO KS, SILVA SLC, DE SOUZA IA, GUALBERTO SA, DA CRUZ RCD, DOS SANTOS FR \& DE CARVALHO MG. 2016. Toxicological evaluation of essential oil from the leaves of Croton tetradenius (Euphorbiaceae) on Aedes aegypti and Mus musculus. Parasitol Res 115: 3441-3448.

CHENG SS, HUANG CG, CHEN YJ, YU JJ, CHEN WJ \& CHANG ST. 2009. Chemical compositions and larvicidal activities of leaf essential oils from two eucalyptus species. Bioresour Technol 100: 452-456.

CHENG SS, LIN C, CHUNG MJ, LIU Y, HUANG CG \& CHANG ST. 2013. Larvicidal activities of wood and leaf essential oils and ethanolic extracts from Cunninghamia konishii Hayata against the dengue mosquitoes. Ind Crops Prod 47: 310-315. 
CHENG Y, DAI C \& ZHANG J. 2017. SIRT3-SOD2-ROS pathway is involved in linalool-induced glioma cell apoptotic death. Acta Biochim Pol 64: 343-350.

DE SOUSA LM ET AL.. 2016. Chemical composition, larvicidal and cytotoxic activities of the essential oils from two Bauhinia species. Rec Nat Prod 10: 341-348.

DERVISHI-SHENGJERGJI D, PAPAJANI V, HAMITI X \& NINGA E. 2014. Chemical composition of Albanian Vitex agnus castus L. leaves essential oils. Int J Ecosyst Ecol Sci 4: 633-636.

DIAS CN \& MORAES DFC. 2014. Essential oils and their compounds as Aedes aegypti L. (Diptera: Culicidae) larvicides: review. Parasitol Res 113: 565-592.

DOOL HVD \& KRATZ PD. 1963. A generalization of the retention index system including linear temperature programmed gas-liquid partition chromatography. J Chromatogr 1: 463-471.

EL-KATTAN AF, ASBILL CS, KIM N \& MICHNIAK BB. 2001. The effects of terpene enhancers on the percutaneous permeation of drugs with different lipophilicities. Int J Phar 215: 229-240.

FANGJUN L \& ZHIJIA Y. 2018. Tumor suppressive roles of eugenol in human lung cancer cells. Thorac Cancer 9: 25-29.

FAYEMIWO KA, ADELEKE MA, OKORO OP, AWOJIDE SH \& AWONIYI IO. 2014. Larvicidal efficacies and chemical composition of essential oils of Pinus sylvestris and Syzygium aromaticum against mosquitoes. Asian Pac J Trop Biomed 4: 30-34.

FUJIWARA GM ET AL. 2017. Evaluation of larvicidal activity and ecotoxicity of linalool, methyl cinnamate and methyl cinnamate/linalool in combination against Aedes aegypti. Ecotox Environ Safe 139: 238-244.

GAUTAM N, MANTHA AK \& MITTAL S. 2014. Essential oils and their constituents as anticancer agents: a mechanistic view. BioMed Res Int 2014: Article ID 154106.

GOIS RWS, DE SOUSA LM, LEMOS TLG, ARRIAGA AMC, ANDRADENETO M, SANTIAGO GMP, FERREIRA YS, ALVES PB \& DE JESUS HCR. 2011. Chemical composition and larvicidal effects of essential oil from Bauhinia acuruana (Moric) against Aedes aegypti. J Essent Oil Res 23: 59-62.

GOVINDARAJAN M. 2010. Chemical composition and larvicidal activity of leaf essential oil from Clausena anisata (Willd.) Hook. f. ex Benth (Rutaceae) against three mosquito species. Asian Pacific J Trop Med 3: 874-877.

JANSEN CC \& BEEBE NW. 2010. The dengue vector Aedes aegypti: what comes next. Microbes Infect 12: 272-279.
JANTAN IB, YALVEMA MF, AHMAD NW \& JAMAL JA. 2005. Insecticidal activities of the leaf oils of eight Cinnamomum species against Aedes aegypti and Aedes albopictus. Pharm Biol 43: 526-532.

KUMAR R, SHARMA S, SHARMA S, KUMARI A, KUMAR D, NADDA G, PADWAD Y, OGRA RK \& KUMAR N. 2016. Chemical composition, cytotoxicity and insecticidal activities of Acorus calamus accessions from the western Himalayas. Ind Crops Prod 94: 520-527.

LESGARDS JF, BALDOVINI N, VIDAL N \& PIETRI S. 2014. Anticancer activities of essential oils constituents and synergy with conventional therapies: a review. Phytother Res 28: 1423-1446.

LIU Y, LIU XC, LIU QY, NIU C \& LIU ZL. 2015. Larvicidal activity of Illicium difengpi BN Chang (Schisandraceae) stem bark and its constituent compounds against Aedes aegypti L. Trop J Pharm Res 14: 103-109.

LUCIA A, AUDINO PG, SECCACINI E, LICASTRO S, ZERBA E \& MASUH H. 2007. Larvicidal effect of Eucalyptus grandis essential oil and turpentine and their major components on Aedes aegypti larvae. J Am Mosq Control Assoc 23: 299-303.

MAR JM, SILVA LS, AZEVEDO SG, FRANCA LP, GOES AFF, DOS SANTOS AL, BEZERRA JA, NUNOMURA RCS, MACHADO MB \& SANCHES EA. 2018. Lippia origanoides essential oil: an efficient alternative to control Aedes aegypti, Tetranychus urticae and Cerataphis lataniae. Ind Crops Prod 111: 292-297.

MARTINS ER, CASALI VWD, BARBOSA LCA \& CARAZZA F. 1997. Essential oil in the taxonomy of Ocimum selloi Benth. J Braz Chem Soc 8: 29-32.

MEDEIROS ES, RODRIGUES IB, LITAIFF-ABREU E, PINTO ACS \& TADEI WP. 2013. Larvicidal activity of clove (Eugenia caryophyllata) extracts and eugenol against Aedes aegypti and Anopheles darlingi. Afr J Biotechnol 12: 836-840.

MENDES LA, MARTINS GF, VALBON WR, DE SOUZA TS, MENINI L, FERREIRA A \& FERREIRA MFS. 2017. Larvicidal effect of essential oils from Brazilian cultivars of guava on Aedes aegypti L. Ind Crops Prod 108: 684-689.

MICHAELAKIS A, VIDALI VP, PAPACHRISTOS DP, PITSINOS EN, KOLIOPOULOS G, COULADOUROS EA, POLISSIOU MG \& KIMBARIS AC. 2014. Bioefficacy of acyclic monoterpenes and their saturated derivatives against the West Nile vector Culex pipiens. Chemosphere 96: 74-80.

MORAES LAS, FACANALI R, MARQUES MOM, MING LC \& MEIRELES MAA. 2002. Phytochemical characterization of essential oil from Ocimum selloi. An Acad Bras Cienc 74: 183-186.

MOREIRA ASN, FERNANDES ROS, LEMOS FJA, BRAZ-FILHO R \& VIEIRA IJC. 2016. Larvicidal activity of Ramalina usnea 
lichen against Aedes aegypti. Braz J Pharmacog 26: 530-532.

MOSMANN T. 1983. Rapid colorimetric assay for cellular growth and survival: application to proliferation and cytotoxicity assays. J Immunol Methods 65: 55-63.

MOTEKI H, HIBASAMI H, YAMADA Y, KATSUZAKI H, IMAI K \& KOMIYA T. 2002. Specific induction of apoptosis by 1,8-cineole in two human leukemia cell lines, but not a in human stomach cancer cell line. Oncol Rep 9: 757-760.

NASCIMENTO JC, BARBOSA LCA, PAUL, VF, DAVID JM, FONTANA R, SILVA LAM \& FRANÇA RS. 2011. Chemical composition and antimicrobial activity of essential oils of Ocimum canum Sims. and Ocimum selloi Benth.. An Acad Bras Cienc 83: 787-799.

NASCIMENTO AMD, MAIA TDS, SOARES TES, MENEZES LRA, SCHER R, COSTA EV, CAVALCANTI SCH \& LA CORTE R. 2017. Repellency and larvicidal activity of essential oils from Xylopia laevigata, Xylopia frutescens, Lippia pedunculosa, and their individual compounds against Aedes aegypti Linnaeus. Neotrop Entomol 46: 223-230.

NEVES RCS \& DA CAMARA CAG. 2016. Chemical composition and acaricidal activity of the essential oils from Vitex agnus-castus L. (Verbenaceae) and selected monoterpenes. An Acad Bras Cienc 88: 1221-1233.

OLIVEIRA MF, LEMOS TLG, DE MATTOS MC, SEGUNDO TA, SANTIAGO GMP \& BRAZ-FILHO R. 2002. New enamine derivatives of lapachol and biological activity. An Acad Bras Cienc 74: 211-221.

PANDEY SK, TANDON S, AHMAD A, SINGH AK \& TRIPHATHI AK. 2013. Structure-activity of monoterpenes and acetyl derivatives against Aedes aegypti (Diptera: Culicidae) larvae. Pest Manag Sci 69: 1235-1238.

PAVELA R. 2015. Essential oils for the development of ecofriendly mosquito larvicides: a review. Ind Crops Prod 76: 174-187.

POLATOGLU K, KARAKOÇ OC, YUCEL YY, GUCEL S, DEMIRCI B, DEMIRCI F \& BASER KHC. 2017. Insecticidal activity of Salvia veneris Hedge. essential oil against coleopteran stored product insects and Spodoptera exigua (Lepidoptera). Ind Crops Prod 97: 93-100.

RAJPUT JD, BAGUL SD, PETE UD, ZADE CM, PADHYE SB \& BENDRE RS. 2017. Perspectives on medicinal properties of natural phenolic monoterpenoids and their hybrids. Mol Divers 22(1): 225-245.

RIELLA KR, MARINHO RR, SANTOS JS, PEREIRA-FILHO RN, CARDOSO JC, ALBUQUERQUE-JUNIOR RLC \& THOMAZZI SM. 2012. Anti-inflammatory and cicatrizing activities of thymol, a monoterpene of the essential oil from Lippia gracilis, in rodents. J Ethnopharmacol 143: 656-663.

SACCHETTI G, MEDICI A, MAIETTI S, RADICE M, MUZZOLI M, MANFREDINI S, BRACCIOLI E \& BRUNI R, 2004. Composition and functional properties of the essential oil of Amazonian basil, Ocimum micranthum Willd., Labiatae in comparison with commercial essential oils. J Agric Food Chem 52: 3486-3491.

SALEH AM, AL-QUDAH MA, NASR A, RIZVI SA, BORAI A \& DAGHISTANI M. 2017. Comprehensive analysis of the chemical composition and in vitro cytotoxic mechanisms of Pallines spinosa flower and leaf essential oils against breast cancer cells. Cell Physiol Biochem 42: 2043-2065.

SAMPATH S, VEERAMANI V, KRISHNAKUMAR GS, SIVALINGAM U, MADURAI SL \& CHELLAN R. 2017. Evaluation of in vitro anticancer activity of 1,8-cineole-containing $n$-hexane extract of Callistemon citrinus (Curtis) Skeels plant and its apoptotic potential. Biomed Pharmacother 93 : 296-307.

SANTOS SRL, MELO MA, CARDOSO AV, SANTOS RLC, DE SOUSA DP \& CAVALCANTI SCH. 2011. Structure-activity relationships of larvicidal monoterpenes and derivatives against Aedes aegypti Linn. Chemosphere 84: 150-153.

SILVA MGV, MATOS FJA, LOPES PRO, SILVA FO \& HOLANDA MT. 2004. Composition of essential oils from three Ocimum species obtained by steam and microwave distillation and supercritical $\mathrm{CO}_{2}$ extraction. Arkivoc 6: 66-71.

TAVAKOLI S, YASSA N, DELNAVAZI MR, AKHBARI M, HADJIAKHOONDI A, HAJIMEHDIPOOR H, KHALIGHI-SIGAROODI F \& HAJIAGHAEE R. 2017. Chemical composition and biological activities of the essential oils from different parts of Ferulago trifida Boiss. J Essent Oil Res 29: 407-419.

TREVISAN MTS, SILVA MGV, PFUNDSTEIN B, SPIEGELHALDER B \& OWEN RW. 2006. Characterization of the volatile pattern and antioxidant capacity of essential oils from different species of the genus Ocimum. J Agric Food Chem 54: 4378-4382.

VASILIJEVIC B, KNEZEVIC-VUKCEVIC J, MITIC-CULAFIC D, ORCIC D, FRANCISKOVIC M, SRDIC-RAJIC T, JOVANOVIC M \& NIKOLIC B. 2018. Chemical characterization, antioxidant, genotoxic and in vitro cytotoxic activity assessment of Juniperus communis var. saxatilis. Food Chem Toxicol 112: 118-125.

VIEIRA PRN, DE MORAIS SM, BEZERRA FHQ, FERREIRA PAT, OLIVEIRA IR \& SILVA MGV. 2014. Chemical composition and antifungal activity of essential oil from Ocimum species. Ind Crops Prod 55: 267-271.

WALIWITIYA R, KENNEDY CJ \& LOWENBERGER CA. 2009. Larvicidal and oviposition-altering activity of monoterpenoids, 
trans-anethole and rosemary oil to the yellow fever mosquito Aedes aegypti (Diptera: Culicidae). Pest Manag Sci 65: 241-248.

\section{How to cite}

RICARTE LP, BEZERRA GP, ROMERO NR, SILVA HC, LEMOS TLG, ARRIAGA AMC, ALVES PB, SANTOS MB, MILITÃO GCG, SILVA TDS, BRAZ-FILHO R \& SANTIAGO GMP. 2020. Chemical composition and biological activities of the essential oils from Vitex-agnus castus, Ocimum campechianum and Ocimum carnosum. An Acad Bras Cienc 92:e20180569. DOI .

Manuscript received on June 7, 2018; accepted for publication on November 13, 2018

\section{LARA P. RICARTE ${ }^{1}$}

https://orcid.org/0000-0002-2627-9957

\section{GABRIELI P. BEZERRA ${ }^{2}$}

https://orcid.org/0000-0002-2398-9021

\section{NIRLA R. ROMERO ${ }^{1}$}

https://orcid.org/0000-0001-7335-8714

\section{HORLANDO C. DA SILVA 3}

https://orcid.org/0000-0001-8996-6095

TELMA L.G. LEMOS 3

https://orcid.org/0000-0002-7031-860X

\section{ANGELA M. C. ARRIAGA ${ }^{3}$}

https://orcid.org/0000-0001-5349-5324

\section{PÉRICLES B. ALVES ${ }^{4}$}

https://orcid.org/0000-0002-8955-9614

\section{MARCELO B. DOS SANTOS 4}

https://orcid.org/0000-0002-3501-4475

\section{GARDENIA C.G. MILITÃ $0^{5}$}

https://orcid.org/0000-0002-7865-5002

\section{THIAGO D.S. SILVA 5}

https://orcid.org/0000-0001-7495-0621

\section{RAIMUNDO BRAZ-FILHO ${ }^{6,7}$}

https://orcid.org/0000-0001-7217-3494

\section{GILVANDETE M.P. SANTIAGO ${ }^{1,2,3}$}

https://orcid.org/0000-0002-6832-8374

'Departamento de Farmácia, Faculdade de Farmácia, Odontologia e Enfermagem, Universidade Federal do Ceará, Rua Capitão Francisco Pedro, 1210, Porangabuçu, 60451-970 Fortaleza, CE, Brazil ${ }^{2}$ Programa de Pós-Graduação em Ciências Farmacêuticas,
Faculdade de Farmácia, Odontologia e Enfermagem, Universidade Federal do Ceará, Rua Capitão Francisco Pedro, 1210, Porangabuçu, 60451-970 Fortaleza, CE, Brazil

${ }^{3}$ Programa de Pós-Graduação em Química, Centro de Ciências, Universidade Federal do Ceará, Av. Mister Hull, s/n, Pici, 60021-970 Fortaleza, CE, Brazil

${ }^{4}$ Departamento de Química, Centro de Ciências Exatas e Tecnologia, Universidade Federal de Sergipe, Av. Marechal Rondon, s/n, Jardim Rosa Elze, 49100-000 São Cristovão, SE, Brazil

${ }^{5}$ Departamento de Fisiologia e Farmacologia, Centro de Ciências Biológicas, Universidade Federal de Pernambuco, Rua Professor Morais Rego 1235, Cidade Universitária, 50670-901 Recife, PE, Brazil

${ }^{6}$ Setor de Química de Produtos Naturais, Universidade Estadual do Norte Fluminense Darcy Ribeiro, Av. Alberto Lamego, 2000, Parque Califórnia, 28013-600 Campos dos Goytacazes, RJ, Brazil ${ }^{7}$ Departamento de Química, Instituto de Ciências Exatas, Universidade Federal Rural do Rio de Janeiro, Rodovia BR 465, Km 07, s/n, Zona Rural, 23890-000 Seropédica, RJ, Brazil

Correspondence to: Gilvandete Maria Pinheiro Santiago E-mail: gil@ufc.br

\section{Author contributions}

Lara P. Ricarte, Gabrieli P. Bezerra and Nirla R. Romero contributed to plants collection and confection of herbarium, running the laboratory work. Lara P. Ricarte, Telma L.G. Lemos, Péricles B. Alves and Marcelo B. dos Santos contributed in the chemical analysis of the essential oils. Horlando C. da Silva, Gardenia C. G. Militão and Thiago D. S. Silva contributed to biological assays. Gilvandete M. P. Santiago designed the study, supervised the laboratory work and wrote the manuscript. Angela M. C. Arriaga and Raimundo Braz-Filho are responsible for reviewing the article. All the authors have read the final manuscript and approved the submission. 